\title{
Pilot CEOs and Corporate Cash Holdings
}

\begin{abstract}
We examine the effect of situation awareness developed from aviation training and experiences on corporate cash policies. We find that firms led by pilot CEOs are more likely to have higher cash holdings and higher market value of cash holdings. The findings suggest that pilot CEOs have greater situation awareness, and that these CEOs are more likely to plan ahead to cope with future liquidity needs. In addition, we find that the level of pilot certification is associated with corporate cash holdings and the value of cash holdings. These findings provide further evidence that situation awareness can be developed through training and aviation experience. We also find that the effect of pilot CEOs on corporate cash holdings is more pronounced for firms with high growth opportunities and firms with financial constraints. These results indicate that pilot CEOs tend to hold more cash when they are aware of future opportunities and risks.
\end{abstract}

Keywords: CEOs; Situation awareness; Cash holdings; Corporate policies; Past experiences; Managerial styles 
"When I learned to fly, I had a crusty, seasoned instructor who gave me a piece of advice about flying that applies equally well to managing a company and executing strategy: "Plan your flight, and fly the plan." - Trevor Fetter, CEO, Tenet Healthcare Corporation. ${ }^{1}$

\section{Introduction}

Do CEOs' past experiences matter? CEOs are often considered to have the most important economic role in shaping corporate policies (Graham et al., 2013). Prior studies show that CEOs' past experiences in life account for the variation in corporate policies that cannot be explained by traditional determinants such as firm, industry or market characteristics. For example, Bamber et al. (2010) find that CEOs' different backgrounds in life affect their firms' voluntary disclosures. Military training has been found to be associated with CEO managerial conservatism (Benmelech and Frydman, 2015), growing up during the Great Depression can create an aversion to risky capital and a preference to utilize tax benefits (Malmendier et al., 2011), and exposure to natural disasters can affect CEOs' risk-taking behavior in corporate decision making (Bernile et al., 2017).

Two recent studies have examined the effect of CEOs' characteristics, captured by pilot certificates, on corporate outcomes. Cain and McKeon (2016) use the pilot certificate as a proxy for personal risk taking and find that pilot CEOs are associated with higher firm risk, as evidenced by higher stock return volatility. They also show that these CEOs have higher propensity to complete value-adding acquisitions for firms with high book-to-market ratios. Sunder et al. (2017) use the pilot license as a proxy for sensation seeking and find that pilot CEOs contribute to corporate innovation success through improving innovation effectiveness. Both studies use the pilot certificate as a proxy for intrinsic personalities such as risk taking and sensation seeking.

\footnotetext{
${ }^{1}$ Available at https://www.dmagazine.com/publications/d-ceo/2007/may/meet-ceo-trevor-fetter/.
} 
However, pilot CEOs could also develop situation awareness from the pilot training and aviation experience. While Cain and McKeon (2016) and Sunder et al. (2017) are silent on the situation awareness trait, it may help to explain why firms managed by pilot CEOs have the capacity to choose value-adding acquisitions, and diverse and original innovation projects.

To further study how pilot CEOs affect corporate decisions, we focus on pilot CEOs' situation awareness and examine its effect on corporate cash holdings. The reasons why we study corporate cash holdings are as follows. First, cash holdings are particularly important to firms as they affect nearly every corporate investment decision (e.g., Almeida et al., 2004; Almeida and Campello, 2007), making managing cash reserves an important decision for firms. Second, setting corporate cash holdings is to a large extent at the discretion of managers (Belghitar and Clark, 2014). CEOs need to assess corporate situations and estimate future unknowns in order to determine corporate cash holdings (Dessaint and Matray, 2017). Therefore, corporate cash holding policy is an important and reasonable setting to examine whether pilot CEOs are sensitive to potential uncertainties and plan ahead to cope with anticipated liquidity risks.

We expect firms led by pilot CEOs to have higher corporate cash holdings. Dessaint and Matray (2017) argue that situation awareness is required when deciding on a company's cash policy, where the $\mathrm{CEO}$ and the management team is required to estimate future unknowns and use their predictions as inputs to make corporate decisions. They find that CEOs tend to increase corporate cash holdings when they anticipate any increase in liquidity risk. Since cash holdings can be used as a buffer against the risk of liquidity shocks (e.g., Opler et al., 1999; Almeida et al., 2004; Han and Qiu, 2007; Campello, 2007; Qiu and Wan, 2015), changes in corporate cash holdings can indicate variations in CEOs' perceived liquidity risk and preference for planning ahead. Prior studies show that pilot CEOs develop situation awareness from pilot training and 
flying experiences, which endows them with the ability to better integrate available information and to plan ahead (e.g., Sarter and Woods, 1991; Endsley, 1995a, 1995b; Endsley and Garland, 2000; Doane et al., 2004 ). Thus, it is possible that pilot CEOs are more aware of potential opportunities and risks, and hence are more likely to reserve cash as safety assets to respond to anticipated liquidity shocks.

In contrast, counter arguments can be mounted to suggest that firms led by pilot CEOs are associated with lower corporate cash holdings. Cain and McKeon (2016) find that pilot CEOs are associated with risk-taking behavior and this risk-taking behavior has been shown to be associated with lower cash holdings. Specifically, CEOs with risk-taking behavior are less worried about corporate uncertainties and thus may not feel the need to hold cash to mitigate the potential liquidity risks (Bernile et al., 2017). In addition, risk-taking CEOs are less likely to constrain their spending, leading to less corporate cash holdings.

We further predict that the value of cash holdings are higher for firms managed by pilot CEOs than other firms. Dessaint and Matray (2017) find that when making assessments for corporate decision making, CEOs can suffer from bias that is consistent with salience theories of choice. They find that managers overact to salient risks, leading to large distortion between perceived and actual risks, and consequently inefficient levels of cash holdings. Prior studies suggest pilot CEOs are apt at noticing minor elements, integrating available information, and planning ahead (e.g., Sarter and Woods, 1991; Endsley, 1995a, 1995b; Endsley and Garland, 2000; Doane et al., 2004). Therefore, they are less likely to be subject to behavioral biases, and are more superior in assessing potential risks and seizing potential opportunities, leading to higher value of cash holdings.

An alternative prediction here is that the value of cash holdings is lower in firms led by pilot CEOs. If pilot CEOs are more likely to be risk takers, they are more likely to spend cash reserves 
recklessly, leading to overinvestment and inefficiency. Moreover, the risk-seeking tendencies could spur CEOs to undertake projects with high uncertainties, resulting in higher losses. Thus, the value of cash holdings for firms led by pilot CEOs may be lower than those for firms led by non-pilot CEOs.

We use pilot certificates as a proxy for situation awareness since CEOs' flying activities are outside of the firms and are less likely to be subject to endogeneity concerns. The data on the pilot CEOs are hand collected using the Federal Aviation Administration (FAA) online airmen credential records. We are able to obtain 245 pilot CEOs and 4,975 non-pilot CEOs, covering 1,707 pilot-CEO firm-years and 16,053 non-pilot-CEO firm-years. Our findings show that firms led by pilot CEOs tend to hold more cash, and are more likely to have higher value of cash holdings.

To provide evidence that situation awareness can be developed through training and aviation experience, we examine the effect of pilot certificate levels on corporate cash holdings and the value of cash holdings. These tests are based on the situation awareness literature, which suggests that expert pilots are more likely to achieve a higher level of situation awareness (Doane et al., 2004; Endsley and Garland, 2000). The findings show that the level of certification has significant positive associations with corporate cash holdings and the value of cash holdings. In additional tests, we find that the effect of pilot CEOs on corporate cash holdings is more pronounced for firms with higher growth opportunities and for firms with financial constraints. These findings are consistent with our conjectures that pilot CEOs tend to hold more cash when they are aware of future opportunities and risks.

Although our study is less likely to be subjected to endogeneity concerns, it is possible that firms with certain characteristics tend to hire pilot CEOs and that those characteristics could be related to corporate cash holdings. To alleviate the endogeneity concern, we conduct a CEO 
turnover analysis following Sunder et al. (2017). The results are consistent with our main findings that firms led by pilot CEOs hold more cash relative to those led by non-pilot CEOs. We also check the robustness of our results by controlling for CEO military experience and also using an alternative measure of corporate cash holdings. Our results are robust and we continue to observe that firms managed by pilot CEOs have higher cash holdings.

Our study contributes to the literature in the following ways. First, it adds to the literature that investigates the effects of CEOs' past experiences on their managerial styles and corporate policies. Prior studies find that the background of managers can influence their guidance disclosure styles (Bamber et al., 2010), ethical behavior (Benmelech and Frydman, 2015), and corporate policies (Malmendier et al., 2011, Bernile et al., 2017). Our study contributes to the literature by documenting an association between CEOs' situation awareness and, both, corporate cash holdings and the value of cash holdings. These findings extend the evidence that CEOs' past experiences are important in corporate decision making.

Second, our study is complementary to two recent studies on pilot CEOs (Cain and McKeon, 2016; Sunder et al., 2017). Cain and McKeon (2016) use pilot licenses as a proxy for CEOs' risk behavior and find that firms managed by pilot CEOs are associated with higher risks. Sunder et al. (2017) use pilot licenses as a proxy for CEOs' sensation seeking and find that pilot CEOs are related to firms' innovation success. Different from their studies, we focus on the situation awareness of pilot CEOs and the development of situation awareness through training and aviation experience. We contribute to the literature on pilot CEOs by showing that different levels of situation awareness can affect corporate policies.

Next, this study builds on the literature that investigates the determinants of corporate cash holdings. In addition to traditional determinants including firm, industry and market characteristics, 
CEO characteristics such as risk taking (Bernile et al., 2017) and optimism (Huang-Meier et al., 2016) also affect corporate cash holdings. However, CEOs' situation awareness has not been documented. This study fills the gap in the literature by using pilot certificates as a proxy for situation awareness and studying the effect of situation awareness on corporate cash holdings. The findings propose an alternative determinant of corporate cash holdings.

The remainder of the paper proceeds as follows. Section 2 reviews related literature and develops our hypotheses. Section 3 describes the research design. Section 4 presents the sample selection and descriptive statistics. Section 5 discusses our main findings. Section 6 presents additional analyses and robustness checks. Section 7 concludes.

\section{Literature Review and Hypotheses Development}

\subsection{Pilot CEOs and Situation Awareness}

In the aviation psychology literature, situation awareness is a well-documented factor attributed to pilot aviation safety and performance. Endsley (1995a) points out that $88 \%$ of aircraft accidents result from human factors and that the lack of situation awareness is one of these key factors. Since situations do not always go to plan, pilots need to be aware of changes, infer potential problems, and take actions to address any issues (e.g., Sarter and Woods, 1991; Endsley, 1995a, 1996b, 2006; Endsley and Garland, 2000). Failing to notice potential risks can cause a loss of control (Doane et al., 2004).

To be better at diagnosing and preventing potential risks, pilots are trained to develop and maintain situation awareness (Horne, 1997). According to the FAA pilot training program, in order to obtain a pilot certificate, individuals need to develop basic knowledge, make adequate planning, keep updating flight situations, predict potential changes, manage crew resources, and plan ahead 
to deal with risks. Endsley (1995a), Horne (1997) and Doane et al. (2004) suggest that situation awareness developed from aviation training and experience allows pilots to assess current flying situations, predict future changes, and be prepared to deal with potential problems, which is essential to pilots' flying performance and safety.

Endsley (1995b) categorizes situation awareness into three different levels. The basic level includes the perception of the elements in the environment. The second level involves the comprehension of the current situation. The third and highest level involves the projection of future status. Novice pilots can achieve the basic level, whereas proficient pilots are associated with a higher degree of situation awareness (Endsley 1995b; Endsley and Garland, 2000). Doane et al., (2004) conduct an experiment to examine pilots' situation awareness and find that expert pilots are more sensitive to future changes, and are better at judging changes than novice pilots.

\subsection{Pilot CEOs and Corporate Cash Holdings}

Setting corporate cash holding policy to meet operation needs is to a large extent at the discretion of managers (Belghitar and Clark, 2014). Managers estimate future unknowns (e.g., customer demand, production costs, competition, and regulatory changes) and use their predictions as inputs to make corporate cash policy (Dessaint and Matray, 2017). Given that cash holdings can be used as a buffer against the risk of liquidity shocks (e.g., Almeida et al., 2004; Han and Qiu, 2007; Opler et al., 1999) ${ }^{2}$, variations in CEOs' perceived liquidity risk and preference for planning-ahead contribute to changes in corporate cash holdings.

\footnotetext{
${ }^{2}$ Cash holdings can be viewed as both a form of low risk investment and a source of financing (Keynes, 1936). Firms tend to accumulate cash since cash holdings can be used as a buffer against the risk of liquidity shocks, which is called the precautionary motive (Keynes, 1936; Opler et al., 1999). Based on the precautionary motive, firms with promising investment opportunities are more likely to accumulate cash since it allows firms to undertake valuable projects when they arise. The precautionary motive also suggests that firms facing financial constraints are more likely to accumulate cash because the influence of future shocks on firms' cash flow will be aggravated when firms have limited access to the external capital market. Subsequent literature provides evidence to highlight the benefits of precautionary cash reserves for firms facing growth opportunities and financial constraints (e.g., Almeida et al., 2004; Han and Qiu, 2007; Almeida and Campello, 2007; Qiu and Wan, 2015).
} 
CEOs with pilot certificates are more likely to develop a higher level of situation awareness from pilot training programs and aviation experience (Horne, 1997). According to the literature on pilot psychology (e.g., Doane et al., 2004; Endsley, 1995a, 1995b), pilots are able to better collect, integrate and assess available information, and are more aware of future opportunities and risks. Moreover, pilots are prone to plan ahead, and to be prepared to respond to potential opportunities and risks (e.g., Doane et al., 2004; Endsley, 1995a, 1996b, 2006; Endsley and Garland, 2000).

Prior literature shows that CEOs' past experiences in other fields account for the variations in corporate policies. Specifically, Bamber et al. (2010) find that managers with military experience are more likely to have more precise disclosure styles, while managers who were born before World War II are more reluctant to make forecasts. Malmendier et al. (2011) find that CEOs who grew up during the Great Depression have a preference for self-sufficiency and tend to avoid risky capital, while CEOs with battlefield experience are more prone to have aggressive corporate policies. Benmech and Frydman (2015) show that military CEOs are less likely to engage in corporate fraudulent activities and more likely to perform better during times of industry distress. Therefore, it is plausible that situation awareness developed from pilot training and aviation experience can influence pilot CEOs' decision making in corporate policies.

Given that pilot CEOs are better at integrating available information, are more aware of future opportunities and risks, and tend to plan ahead, it is possible that pilot CEOs are more likely to accumulate cash for a precautionary motive to cope with anticipated uncertainties and opportunities. Our first hypothesis is stated as follows.

H1a: Firms managed by CEOs with pilot certificates are more likely to have higher corporate cash holdings.

It is also possible that there could be a negative relationship between pilot CEOs and corporate 
cash holdings. CEOs with pilot certificates are found to be associated with risk-taking behavior (Cain and McKeon, 2016). Higher risk taking indicates less demand for cash (e.g., Bernile et al., 2017; Tong, 2010). Although pilot CEOs anticipate future situations, their risk-taking trait encourages them to be less worried about corporate uncertainties. Therefore, they are not prone to reserve cash as safe assets to mitigate liquidity risks. Also, it could be the case that pilot CEOs have a tendency to spend cash. For example, Cain and McKeon (2016) find that firms managed by pilot CEOs are more acquisitive than other firms, which indicates that pilot CEOs may rush to spend cash. As a result, CEOs with pilot certificates may take more risks and spend more cash, leading to less corporate cash holdings.

H1b: Firms managed by CEOs with pilot certificates are less likely to have higher corporate cash holdings.

\subsection{Pilot CEOs and the Value of Cash Holdings}

Generally, CEOs are expected to make decisions for the sake of increasing firm value. However, prior literature in psychology suggests that individuals are subject to behavioral biases and do not always use all available information to estimate probabilities (e.g., Tversky and Kahneman, 1973, 1974). Graham et al. (2015) show that up to one half of CEOs make their investment decisions based on their "gut feeling”. Dessanit and Matray (2017) provide empirical evidence that CEOs pay attention to salient information and make mistakes in their assessment of firms' situations, which contributes to the inefficient level of corporate cash holdings.

Pilot CEOs, who developed situation awareness from aviation training and experience, have the ability to process more available information related to their goals (e.g., Endsley 1995a, 1995b; Endsley and Garland, 2000). They are more sensitive to minor elements, are able to connect 
seemingly unrelated factors successfully, and are better at assessing potential opportunities and risks (Doane et al., 2004). Therefore, CEOs with pilot certificates are less likely to be subject to behavioral biases and are more likely to invest in value-increasing projects, leading to higher value of corporate cash holdings.

Furthermore, pilot CEOs tend to plan ahead and to prepare for future actions (e.g., Doane et al., 2004; Endsley, 1995a, 1996b, 2006; Endsley and Garland, 2000). It is possible that firms managed by these CEOs reserve cash so that they can quickly seize worthy projects. Qiu and Wan (2015) argue that seizing valuable opportunities generates great benefits for firms through enhancing the firms' competitive advantage. These benefits attribute to investment efficiency and higher marginal value of cash holdings. Taken together, we expect that CEOs with pilot certificates could benefit firms through their ability to avoid making wrong judgements and their preference of planning-ahead. Our hypothesis is stated as follows.

H2a: Firms managed by pilot CEOs are more likely to have higher value of corporate cash holdings.

However, the value of cash holdings could be lower in firms led by CEOs with pilot certificates. If pilot CEOs are more likely to take risks, they may spend cash reserves recklessly, leading to overinvestment and inefficiency. In addition, the tendency to take risks may encourage CEOs to undertake projects with higher uncertainties (Cain and McKeon, 2016). Therefore, it is also possible that firms managed by these CEOs are more likely to experience losses from these projects, which is detrimental to the value of cash holdings.

H2b: Firms managed by pilot CEOs are more likely to have lower value of corporate cash holdings. 


\section{Research Design}

\subsection{Research Design for $\mathrm{HI}$}

To examine the effect of pilot CEOs on corporate cash holdings, we estimate the following model:

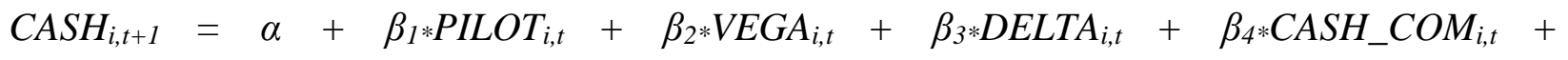

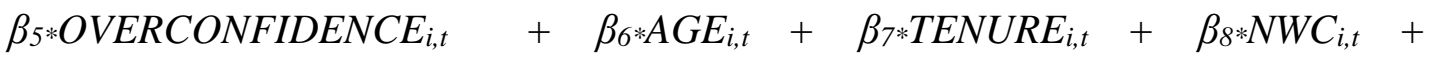

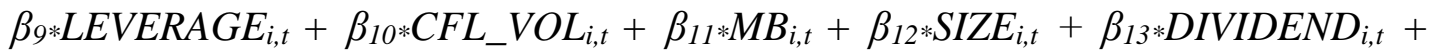

$$
\begin{aligned}
& \beta_{14 * C A P E X_{i, t}}+\beta_{15 * A Q U_{i, t}}+\beta_{16 * C F L_{i, t}}+\beta_{17 * R \& D_{i, t}+\beta_{18 * T A N G I B I L I T Y}{ }_{i, t}+}+ \\
& \beta_{19 * S A L E S} G_{i, t}+\beta_{20} * R O E_{i, t}+\text { Industry FE }+ \text { Year FE }+\varepsilon_{i, t}
\end{aligned}
$$

where $\mathrm{CASH}_{i, t+1}$ is the cash-to-asset ratio in year $t+1$. PILOT $_{i, t}$ is an indicator variable which is equal to one if the firm's CEO has a pilot certificate and zero otherwise. We are interested in the coefficient on PILOT $T_{i, t}$.

Following Cain and McKeon (2016), we control for CEO-specific variables, including CEOs' incentives induced by their compensation contracts $\left(V E G A_{i, t} D E L T A_{i, t}\right.$ and $\left.C A S H_{-} C O M_{i, t}\right)$, CEO overconfidence (OVERCONFIDENCE $\left.E_{i, t}\right)$, CEO age $\left(A G E_{i, t}\right)$, and CEO tenure $\left(T E N U R E_{i, t}\right)$. Specifically, $V E G A_{i, t}$ is the dollar change in CEO's option holdings for a $1 \%$ change in stock return volatility. DELTA $A_{i, t}$ is the dollar change in CEO stock and option portfolio value for a $1 \%$ change in stock price. $C_{A S H} C_{C O M}$ is the CEO's cash compensation. OVERCONFIDENCE $E_{i, t}$ is an indicator variable which is equal to one if the CEO vested the options exceeds the $100 \%$ moneyness in the current period or any prior period. $A G E_{i, t}$ is the natural logarithm of CEO age. TENURE $E_{i, t}$ is the number of years of service as CEO at given firm.

Following prior literature on corporate cash holdings (Fresard, 2010; Gao et al., 2013), we also control for a set of firm characteristics. Specifically, we include net working capital $\left(N W C_{i, t}\right)$, leverage ( $\left.L E V E R A G E_{i, t}\right)$, volatility of cash flows $\left(C F L_{-} V O L_{i, t}\right)$, market-to-book ratio $\left(M B_{i, t}\right)$, firm 
size $\left(S I Z E_{i, t}\right)$, an indicator variable which equals one if a firm pays a common dividend $\left(D_{V I D E N D}, t\right)$, capital expenditures $\left(C A P E X_{i, t}\right)$, acquisition expenses $\left(A Q U_{i, t}\right)$, free cash flow $\left(C F L_{i, t}\right)$, research and development expenditures $\left(R \& D_{i, t}\right)$, assets tangibility (TANGIBILITY $\left.Y_{i, t}\right)$, sales growth $\left(S A L E S \_G_{i, t}\right)$, and return on equity $\left(R O E_{i, t}\right)$. Detailed variable definitions and data sources are presented in Appendix 1.

\subsection{Research Design for $\mathrm{H} 2$}

To test $\mathrm{H} 2$, we examine the impact of pilot CEOs on the value of an additional dollar of cash to shareholders. We adapt the model from Faulkender and Wang (2006) by including the dummy variable for pilot CEOs and an interaction term between that variable and the change in cash holdings. We also control for CEO's DELTA and VEGA in the regression since prior studies show that CEO's DELTA and VEGA significantly affect the value of corporate cash holdings (e.g., Tong, 2010; Liu and Mauer, 2011). The model is stated as follows.

$$
\begin{aligned}
& R_{i, t}-R B_{i, t}=\alpha+\beta_{1} * P I L O T_{i, t}+\beta_{2} * P I L O T_{i, t} * \Delta C A S H_{i, t}+\beta_{3} * \Delta C A S H_{i, t}+\beta_{4} * \Delta E A R N_{i, t}+\beta_{5} * \Delta R D_{i, t}+ \\
& \beta_{6} * \Delta N A_{i, t}+\beta_{7} * \Delta I_{i, t}+\beta_{8} * \Delta D_{i, t}+\beta_{9} * C A S H_{i, t-1}+\beta_{10} * L E V_{i, t}+\beta_{11} * C A S H_{i, t-1} * \Delta C A S H_{i, t} \\
& +\beta_{12} * L_{E V} V_{i, t}^{*} \triangle \mathrm{CASH}_{i, t}+\beta_{13} * \mathrm{NEWFIN}_{i, t}+\beta_{14} * \mathrm{DELTA}_{i, t}+\beta_{15} * V_{E G A_{i, t}}+ \\
& \beta_{16} * D_{E L T A} A_{i, t} * \Delta C A S H_{i, t}+\beta_{17} * V E G A_{i, t} * \Delta C A S H_{i, t}+\text { Industry FE }+ \text { Year FE }+\varepsilon_{i, t}
\end{aligned}
$$

where $R_{i, t}$ is the stock return over fiscal year $t-1$ to $t$, which is estimated using monthly returns from CRSP. $R B_{i, t}$ represents firm $i$ 's Fama and French 25-portfolio benchmark return over fiscal year $t^{-1}$ to $t$. To determine the benchmark, we group every firm in our sample into one of the 25 portfolios sorted by size and book-to-market. The excess return $\left(R_{i, t}-R B_{i, t}\right)$ is the difference between firm stock return over year t-1 to year $\mathrm{t}$ and the Fama and French 25 portfolios benchmark return over fiscal year $t-1$ to year $t$.

PILOT $_{i, t}$ is an indicator variable that takes on the value of one for CEOs with pilot certificate and zero otherwise. $\Delta X_{i, t}$ represents a change in the variable $X$ of firm $i$ from year $t$ - 1 to $t$. (e.g., 
$\left.\Delta C A S H_{i, t}=C A S H_{i, t}-C A S H_{i, t-1}\right) . C A S H_{i, t}$ represents the total cash and marketable securities. $E A R N_{i, t}$ represents earnings before extraordinary items. $R D_{i, t}$ represents research and development expenses, set as zero if missing. $N A_{i, t}$ represents net assets. $I_{i, t}$ represents interest expenses. $D_{i, t}$ represents common dividends payout. $\mathrm{CASH}_{i, t-1}$ represents the one year lagged cash and marketable securities. $L E V_{i, t}$ represents the sum of long-term debt and current liabilities. NEWFIN ${ }_{i, t}$ represents net new finance. $D_{E L T A}$ is is the the dollar change in CEO stock and option portfolio value for a $1 \%$ change in stock price. $V E G A_{i, t}$ is the dollar change in CEO's option holdings for a $1 \%$ change in stock return volatility. All independent variables, except for $P I L O T_{i, t}, D E L T A_{i, t}$ and $V E G A_{i, t}$, are scaled by market value of equity at year $\mathrm{t}-1$.

\section{Sample Selection and Descriptive Statistics}

\subsection{Sample Selection}

Our initial sample comprises of CEOs at US firms between 1992 and 2015. The data are retrieved from the ExecuComp database which mainly provides information on the top paid executives of Standard \& Poor's (S\&P) 1500 Index. This gives us 7,560 unique CEOs.

We search for each CEO on the Federal Aviation Administration (FAA) online airmen inquiry website. $^{4}$ The name searching is based on the CEO's first name, middle initial, and last name. If a CEO name does not produce a match in the FAA inquiry website, we categorize that CEO as a non-pilot. If a CEO name produces at least one name match in the FAA inquiry website, we categorize that CEO as a possible pilot. For these possible pilot CEOs, we need to further verify

\footnotetext{
${ }^{4}$ The FAA website is https://amsrvs.registry.faa.gov/airmeninquiry/. The FAA website also provides a downloadable version of the airmen database. However, the downloadable database does not contain the date of birth of the pilot and their address information. As a result, we are unable to ensure the accuracy of the matches if simply matched the CEOs names using the FAA downloadable airmen database. Instead, we use the FAA online inquiry website to ensure the accuracy of matches and increase the sample size.
} 
the accuracy of the matching. The procedure of verification differs slightly for the following two sample period: (1) 1992 to 2010 and (2) 2010 to 2015. This is because pilot CEOs data on the period 1992 to 2010 was shared with us by Cain and McKeon (2016). ${ }^{5}$

For the sample period of 1992 to 2010, 4,346 non-pilot CEOs and 2,179 possible pilot CEOs are generated after searching for the CEOs names on the FAA online inquiry website. We ensure the accuracy of the matching by using the pilot CEOs list provided to us by Cain and McKeon (2016). We are able to identify the 179 pilot CEOs among the 2,179 possible pilot CEOs. Consequently, we deleted the 2,000 remaining names that were not matched.

For the sample period of 2011 to 2015, 629 non-pilot CEOs and 406 possible pilot CEOs are generated after searching for the CEO names on the FAA online inquiry website. For this sample period, we need to use other information such as the CEO address or CEO's date of birth to verify the accuracy of the matching. Since the CEO's address can change, we use the date of birth to verify the matching. We collect the CEOs' date of birth from LexisNexis, the Notable Names Database (NNDB), BoardEx, and public records. In some cases where the exact birth date is unavailable, we use only the month and year of birth. After entering the date of birth, if the match remains valid, we identify that CEO as a pilot. Due to limited access to CEOs' biographical information and in particular the date of birth, we are only able to identify 66 pilot CEOs among 406 possible CEOs names. We deleted the remaining 340 names that we are not able to verify, which is consistent with the sample selection criteria for the sample period 1992 to 2010. In the final sample, we have 245 pilot CEOs and 4,975 non-pilot CEOs. Our selection process for pilot CEOs and non-pilot CEOs is detailed in Figure 1.

We obtain cash holding data from COMPUSTAT between 1989 and 2016. We require four

\footnotetext{
${ }^{5}$ We would like to thank for the authors of Cain and McKeon (2016) for sharing their pilot CEO names. Their sample period is between 1992 and 2010, covering 179 pilot CEOs.
} 
years of data (1989 through 1992) to compute cash flow volatility for the first year of our sample period. ${ }^{6}$ The stock returns data is obtained from CRSP. We exclude financial firms (SIC codes 6000-6999) due to their special statutory capital requirements. We also exclude firms in the utility sector (SIC codes 4900-4999) because of their special regulatory environment. Any firms with incomplete data are excluded except for those with missing R\&D expenditure (we set the missing R\&D values as zero) and capital expenditure (again, we set the missing capital expenditure as zero). Our sample therefore consists of 1,707 CEO-pilot firm-year observations and 16,053 nonpilot firm-year observations. In the analyses of the effect of pilot CEOs on the value of cash holdings, we further restrict our sample to firm-years that have positive market value of equity.

\subsection{Descriptive Statistics}

Table 1 reports the descriptive statistics for the CEOs included in the FAA airmen certificates records. Panel A reports the different levels of pilot certificates held by CEOs. Among 245 pilot CEOs in our sample, 20 CEOs have student pilot certificates. According to the FAA airplane airman certification standards, student pilot is the lowest level of certification that a pilot can obtain and allows the pilot to fly alone in an aircraft. The majority of pilot CEOs (156) hold private pilot certificates which requires pilots to command a wide range of aircrafts but not for the commercial purpose. Pilots in this level exhibits satisfactory skills, knowledge and risk management. 15.5\% and $8.2 \%$ of pilot CEOs reach higher levels, obtaining commercial and airline transport pilot certificates, respectively. According to the FAA pilot certificate level requirement, these two levels require more rigorous training and examination. Pilots' insurance premium can be reduced if they

\footnotetext{
${ }^{6}$ We collect our independent variable between 1992 and 2015. The sample period refers to the period that we examine the corporate cash holdings between 1993 and 2016. We download the Compustat data from 1988 because we need four years of lagged data to calculate volatility of cash flows, which measured by the standard deviation of annual changes of cash flow from operation over four-year lagged period.
} 
hold higher levels of certificates, this is because higher levels of certificates are evidence of experience and better skills (Cain and McKeon, 2016).

Panel B of Table 1 reports the certificate ratings held. The ratings provide pilots with a variety of "flight privileges". Specifically, about $37 \%$ of the pilot CEOs hold an instrument rating, which permits them to fly under conditions in which the view is obstructed (Cain and McKeon, 2016). About a third of the pilot CEOs hold a multiengine airplane rating, which allows them to operate multiple-engine airplanes. As for the other class ratings, the pilots in our sample are able to fly helicopters (14), gliders (6), sea landing airplanes (9), and hot air balloons (2).

Panel C of Table 1 reports the correlations among a variety of CEOs characteristics. The positive correlation between PILOT and VEGA/DELTA indicates that pilot CEOs are likely to have compensation packages with high risk incentives. This provides support for the need to control for DELTA and VEGA in the regression models.

Panel A of Table 2 presents the descriptive statistics for all the variables used in our regression of corporate cash holdings. Panel B of Table 2 reports descriptive statistics for the pilot CEO sample and the non-pilot CEO sample separately. We perform t-tests to compare the sample means between the firms with pilot CEOs and firms without pilot CEOs.

We find important differences in the characteristics of the firms in the two groups. Firms led by pilot CEOs are more likely to have relatively high cash holdings $(C A S H)$. Firms run by pilot CEOs are also more likely to have a higher leverage ratio (LEVERAGE), which is consistent with the findings of prior studies (e.g., Cain and McKeon, 2016). Also, pilot CEO firms are larger (SIZE), have lower net working capitals $(N W C)$, have higher free cash flows $(C F L)$, have more tangible assets (TANGIBILITY), and are more likely to pay dividend (DIVIDEND). 
Perhaps not surprisingly, we find that CEOs with pilot certificates are more likely to have higher pay-performance sensitivity (DELTA) and higher risk incentives (VEGA) in their compensation packages, which is again consistent with the findings in Cain and McKeon (2016). In addition, pilot CEOs are relatively younger $(A G E)$, have longer tenure, and have more cash compensation $\left(\mathrm{CASH}_{-} \mathrm{COM}\right)$.

\section{Main Results}

\subsection{Effects of Pilot CEOs on Corporate Cash Holdings (Test of H1)}

Table 3 represents the regression results of cash holdings on firms with pilot CEOs and controls. The regression includes time fixed effects and industry fixed effects (i.e., year dummies and three-digit SIC code dummies). We use the one year ahead cash holdings as dependent variable to alleviate the endogeneity concern. The robust standard errors are clustered by year and firm level.

We focus on the coefficient on PILOT, which captures the relation between pilot CEOs and corporate cash holdings. After controlling for firm characteristics and CEO characteristics, the coefficient on PILOT is 0.014 , and it is statistically significant at the 5\% significant level (p-value $=0.049)$. This reveals that pilot CEOs are positively related to corporate cash holdings. The positive relation between pilot CEOs and corporate cash holdings is also economically significant. Specifically, pilot CEOs are associated with increases in corporate cash reserves of 0.014 . The findings support H1a that firms led by pilot CEOs tend to hold more cash.

With respect to the other CEOs characteristics, we find that coefficient signs and magnitudes on VEGA, DELTA and CASH_COM are similar to the findings of Tong (2010). VEGA is negatively related to the corporate cash holdings. The coefficient on VEGA is -0.003 and significant at $1 \%$ level $(\mathrm{p}$-value $=0.006)$. This implies that firms managed by CEOs with higher risk-incentive have 
a lower level of cash holdings. The coefficient on DELTA is 0.007 and statistically significant at $1 \%$ level (p-value $=0.000)$. In addition, the results show that OVERCONFIDENCE is negatively related to corporate cash holdings, which is similar to the findings of Bernile et al. (2017). The coefficients on firm characteristics are generally consistent with prior studies (e.g., Tong, 2010; Liu and Mauer, 2011).

\subsection{Effects of Pilot CEOs on the Value of Cash Holdings (Test of H2)}

So far, the results show a positive relation between pilot CEOs and corporate cash holdings. To get a better understanding of whether this is beneficial or detrimental to the firms, we examine the value of cash holdings in firms managed by pilot CEOs. Table 4 reports the results of relation between pilot CEOs and the value of cash holdings. Standard errors are clustered by year and firm level. We find that the coefficient of the interaction term between PILOT and $\triangle C A S H$ is positive and statistically significant at $5 \%$ level, which is 1.753 (p-value $=0.037$ ). The findings are consistent with hypothesis H2a that firms managed by pilot CEOs are more likely to have higher value of cash holdings. Overall, the results support the interpretation that CEOs who have developed situation awareness are more superior in assessing potential projects.

\section{Additional Analyses and Robustness Checks}

\subsection{Certificate Levels}

To further examine the effects of situation awareness, we conduct additional analyses based on the pilot certificate levels. As expert pilots are more likely to achieve high level of situation awareness (Endsley et al., 1998; Endsley and Garland, 2000; Doane et al., 2004; Endsley, 2006), we therefore expect CEOs with a higher level pilot certificate to have higher corporate cash holdings, than CEOs with a lower level certificate. We use Equation (1) and replace the PILOT 
dummy variable with the HIGHLEVEL and LOWLEVEL dummy variables. ${ }^{7} H I G H L E V E L$ equals to one if the CEO has a certificate in FAA airmen database and the certificate level is above private pilot, and zero otherwise. $L O W L E V E L$ equals to one if the CEO has a certificate in FAA database and the certificate level is below or equal to private pilot, and zero otherwise.

Table 5 represents the results on the effect of CEOs with high level and low level of pilot certificate on corporate cash holdings. The estimated coefficient on CEOs with high level of certificate (HIGHLEVEL) is positive as expected. The magnitude of coefficient is 0.040 , and statistically significant at $1 \%$ level $(\mathrm{p}$-value $=0.009)$. Comparing with the coefficient on PILOT reported at Table 3, the coefficient magnitude is increased by $0.026(0.040-0.014)$. While the estimated coefficient on CEOs with low level of certificate (LOWLEVEL) is positive and its magnitude is 0.005 , it is not statistically significant ( $\mathrm{p}$-value $=0.481$ ). The coefficients of control variables are generally consistent with the results of Table 3 . The findings support our conjecture that CEOs with high pilot certificate level are more likely to have higher level of situation awareness. Furthermore, the differences between the coefficient magnitudes on CEOs with high certificate level and low certificate level support the pilot certificate as a reasonable proxy for situation awareness. That is because the situation awareness is increasing in pilots' expertise while risk taking or sensation seeking is not.

We further test the differences between the effects of pilot CEOs with high or low certificate level on the value of corporate cash holdings. We use Equation (2) and replace PILOT with HIGHLEVEL and LOWLEVEL. We substitute the interaction PILOT* $\triangle C A S H$ by two interactions $(H I G H L E V E L * \triangle C A S H$ and $L O W L E V E L * A C A S H)$. The control variables are exactly as in Table 4. Robust standard errors are clustered by year and firm level. We focus on the coefficients on the

\footnotetext{
${ }^{7}$ The benchmark group comprises CEOs who do not hold a pilot certification.
} 
HIGHLEVEL ${ }^{*} \triangle C A S H$ and $L O W L E V E L * \triangle C A S H$. The expectations is that the coefficients on these two interactions remain positive, indicating that firms led by pilot CEOs are more likely to have higher value of cash holdings. We also examine the difference between the magnitude of coefficient on HIGHLEVEL ${ }^{*} \triangle C A S H$ and on LOWLEVEL ${ }^{*} \triangle C A S H$.

The results show that coefficients on the interaction terms are positive, consistent with the preceding findings that pilot CEOs contribute to higher value of cash holding in their firms. In addition, the coefficient on $L O W L E V E L{ }^{*} \triangle C A S H$ is not statistically significant, while coefficient on HIGHLEVEL ${ }^{*} \triangle C A S H$ is significant at $1 \%$ level (p-value $\left.=0.007\right)$. The magnitude on $H I G H L E V E L * \triangle C A S H$ is much bigger relative to the magnitude on $L O W L E V E L * \triangle C A S H$ (5.796 relative to 1.064). These findings are consistent with the interpretation that pilot CEOs with higher certificate levels are more likely to have higher level of situation awareness, which contributes to more efficient use of the cash holdings.

\subsection{Growth Opportunities}

To better understand if pilot CEOs with situation awareness are better at assessing situations and are more aware of future opportunities, we conduct additional tests on whether growth opportunities affect the effect of pilot CEOs on cash reserves. The industries are classified based on the SIC three-digit codes. Industry's growth options are measured by market-to-book ratio at year $t$. Following Faulkender and Wang (2006), higher (lower) level of growth options is classified according to market-to-book above (below) the median. We then separate firms into two subsamples based on these firms with higher or lower industry's growth options. We use regression (1) to perform this test, and the control variables are exactly as in Table 3.

Table 7 reports the results of the subsample analyses. The first column reports the regression results of firms with lower growth opportunities. The coefficient on PILOT is 0.014 , significant at 
$10 \%$ level. It indicates that pilot CEOs are associated with increase in corporate cash holdings of 0.014 when firms have lower growth opportunities. The second column shows the regression results for firms with higher growth opportunities, where the coefficient on PILOT is 0.026 (significant at 5\% level). This indicates that pilot CEOs are associated with increase in corporate cash holdings of 0.026 when firms face higher growth opportunities. The coefficient magnitude on PILOT when firms have higher growth opportunities is almost double the coefficient magnitude on PILOT that firms have lower growth opportunities. These results suggest that the effect of pilot CEOs on corporate cash holdings is more pronounced for the firms with higher growth opportunities. These findings are consistent with our conjecture that pilot CEOs tend to hold more cash when they are anticipating higher growth opportunities.

\subsection{Financial Constraints}

To further investigate if pilot CEOs with situation awareness are better at assessing situations and more sensitive to future risks, we conduct tests to examine how financial constraints affect the effect of CEOs' situation awareness. Following Alemeida et al. (2004), we measure financial constraints as the payout ratio, which is calculated as the sum of stock repurchase and dividends scaled by the total assets. We sort all firms for each year based on their pay-out ratio, and separate firms above and below the median into two subsamples, i.e., with financial constraints and without financial constraints. The control variables are exactly as in Table 3. Robust standard errors are clustered at year and firm level.

Table 8 reports the results of subsample analysis. The first column represents the regression on firms that are not financially constrained. The coefficient on PILOT is positive but not statistically significant $(\mathrm{p}=0.139)$. The second column show the regression for firms with financial constraints, where the estimated coefficient on PILOT is significant at the 5\% level $(\mathrm{p}=0.038)$. 
Moreover, the magnitude of coefficient on PILOT (0.020) is larger for the financially constrained firms relative to the other firms (0.015). These results suggest that the effect of pilot CEOs on corporate cash holdings is more pronounced for the firms with financial constraints. The findings support our prediction that pilot CEOs with situation awareness are more prone to plan-ahead to cope with anticipated uncertainties.

\subsection{CEO Turnover}

We find firms led by pilot CEOs tend to hold more cash. However, it is possible that firms with certain characteristics tend to hire pilot CEOs and those characteristics could be related to corporate cash holdings. To mitigate the endogeneity concern, we focus on CEO turnover following Sunder et al. (2017) to investigate the change in corporate cash holdings. We select firms that have a CEO turnover at year $t-1$ and are able to obtain 391 pilot CEO turnover observations. We regress the change in cash holdings on PILOTTURNOVER. The PILOTTUROVER variable is equal to one when the firm has a non-pilot CEO at year $t-l$ and a pilot CEO at year $t$ and is equal to negative one when the firm has a pilot CEO at year $t-l$ and has a non-pilot CEO at year $t .{ }^{8}$ The variable of interest is PILOTTURNOVER. The coefficient on PILOTTURNOVER reveals the effect of pilot CEO, comparing with non-pilot CEO, on corporate cash holdings for the same firm.

We calculate the changes in variables between year $t-1$ and year $t+1$. Specifically, the change in cash holdings is measured as the difference between the cash-to-asset ratio after the new CEO takes office and the cash-to-asset ratio measured when the previous CEO was in power. We control for the changes in CEO characteristics. Similar to the calculation of change in cash holdings, we calculate the changes in control variables as the difference between these variables measured at year $t+1$ and year $t-1$. We do not include the changes in firm characteristics in regression because

\footnotetext{
${ }^{8}$ It is important to note that we do not include an intercept in this model.
} 
there are a lot of missing values in these variables and the sample size becomes very small if we control for them.

Table 9 show the results for the subsample that firms with pilot CEO turnover. The estimated coefficient on PILOTTURNOVER is positive and statistically significant at 5\% level (pvalue $=0.013$ ). The magnitude of the coefficient is 0.052 . The findings support the notion that CEOs with pilot certificates have an active effect on corporate cash holdings.

\subsection{Controlling for Military Experience}

Some pilots served in the United State Air Force, and Cain and McKeon (2016) show that there is a positive correlation between the PILOT and MILITARY. It is possible that CEOs with military experience may developed risk-taking behavior during their service (Cain and McKeon, 2016). In addition, CEOs with battlefield background are likely to developed situation awareness from being in combat (Riley et al., 2006). Thus, we perform an additional test by including the CEO military experiences and using a subsample from 2011 to 2016 . We hand-collect military CEO data from LexisNexis. The sample used in the following analysis includes 61 military CEOs, covering 154 military CEO firm-year observations between 2011 and 2016. Table 10 represents the results after controlling for the CEO's military experience (MILITARY). The estimated coefficient on MILITARY is positive but not significant. The estimated coefficient on PILOT remains positive and significant at $10 \%(\mathrm{p}$-value $=0.051)$. We continue to find that the pilot CEOs are positively related to corporate cash holdings.

\subsection{Alternative Definition of Cash Holdings}

We employ an alternative measure of cash holdings following Hanlon et al. (2017) to ensure that the prior findings on the positive relation between the pilot CEOs and corporate cash holdings are not driven by the choice of measures. Specifically, we use the log of cash-to-assets ratio as the 
dependent variable to examine the effect of pilot CEOs on corporate cash holdings $(\log (\mathrm{CASH}))$. Table 11 reports the results using the $\log (C A S H)$ as the dependent variable. The estimated coefficient on PILOT is positive and statistically significant at $1 \%(\mathrm{p}$-value $=0.008)$. Our findings that firms managed by pilot CEOs have higher cash holdings are robust to this alternative specification of cash holdings.

\section{Conclusion}

This study examines whether situation awareness proxied by pilot CEOs affects corporate cash holdings and the value of cash holdings. We find that firms led by pilot CEOs tend to hold more cash and are more likely to have a higher value of cash holdings. Consistent with the notion that the positive effects of pilot CEOs come from situation awareness, we further show that CEOs with a high pilot certificate level tend to hold more cash than CEOs with a low pilot certificate level. In addition, we find that the effect of pilot CEOs on corporate cash holdings is more pronounced for firms with higher growth opportunities and firms with financial constraints. The findings suggest that pilot CEOs with situation awareness are more likely to plan ahead to seize future opportunities and cope with anticipated uncertainties.

This study has several implications. First, our results provide evidence that CEOs' past experiences in life can have an effect on CEOs' managerial styles. Specifically, pilot CEOs develop situation awareness from aviation training and flying experience, which can affect their decision-making relating to corporate cash holdings. Second, this study has practical implications for firms by providing an alternative explanation of why pilot CEOs are more likely to undertake value-adding acquisitions and diverse and original innovation projects. Firms may potentially use

pilot certification to identify CEOs who are likely to be aware of potential opportunities and risks 
and who tend to plan ahead. Third, this study provides additional insights into the determinants of corporate cash holdings and the value of cash holdings, suggesting that proxies such pilot certification may capture the characteristics of CEOs that may not be measured conventionally. 


\section{References}

Almeida, H., Campello, M. \& Weisbach, M.S. 2004, "The Cash Flow Sensitivity of Cash", The Journal of Finance, vol. 59, no. 4, pp. 1777-1804.

Almeida, H. \& Campello, M. 2007, "Financial Constraints, Asset Tangibility, and Corporate Investment", The Review of Financial Studies, vol. 20, no. 5, pp. 1429-1460.

Bamber, L.S., Jiang, J.\& Wang, I.Y. 2010, "What's My Style? The Influence of Top Managers on Voluntary Corporate Financial Disclosure", The Accounting Review, vol. 85, no. 4, pp. 11311162.

Bates, T.W., Kahle, K.M. \& Stulz, R.M. 2009, "Why Do U.S. Firms Hold so Much More Cash than They Used To?", The Journal of Finance, vol. 64, no. 5, pp. 1985-2021.

Bernile, G., Bhagwat, V. \& Rau, P.R. 2017, “What Doesn't Kill You Will Only Make You More Risk-Loving: Early-Life Disasters and CEO Behaviour”, The Journal of Finance, vol. 72(1), 167-206.

Benmelech, E. \& Frydman, C. 2015, "Military CEOs", Journal of Financial Economics, vol. 117, no. 1 , pp. 43-59.

Belghitar, Y.\& Clark, E. 2014, "Convexity, Magnification, and Translation: The Effect of Managerial Option-based Compensation on Corporate Cash Holdings: Convexity, magnification, and translation", Journal of Financial Research, vol. 37, no. 2, pp. 191-210.

Cain, M.D. \& McKeon, S.B. 2016, "CEO Personal Risk-Taking and Corporate Policies", Journal of Financial and Quantitative Analysis, vol. 51, no. 1, pp. 139-164.

Doane, S.M., Sohn, Y.W. \& Jodlowski, M.T. 2004, "Pilot Ability to Anticipate the Consequences of Flight Actions as a Function of Expertise", Human Factors: The Journal of the Human Factors and Ergonomics Society, vol. 46, no. 1, pp. 92-103.

Dessaint, O. \& Matray, A. 2017, "Do managers overreact to salient risks? Evidence from Hurricane Strikes", Journal of Financial Economics, vol. 126, no. 1, pp. 97-121.

Endsley, M. R. 1995a, “A Taxonomy of Situation Awareness Errors”, In R. Fuller, N. Johnson, \& N. McDonald (Eds.), Human factors in aviation operations, pp. 287-292. Aldershot, England: Avebury Aviation, Ashgate Publishing.

Endsley, M. R. 1995b, "Toward a Theory of Situation Awareness in Dynamic Systems",Human Factors, vol. 37, no. 1, pp. 32-64.

Endsley, M.R. 2006, "Expertise and Situation Awareness", In K.A.Ericsson, N.Charness, P.J.Fetovich, \& R. R. Hoffman (Eds.), The Cambridge Handbook of Expertise and Expert Performance. pp. 635-651. New York, NY: Cambridge University Press.

Endsley, M.R., Farley, T.C., Jones, W. M., Midkiff, A. H. \& Hansman, R. J. 1998, "Situation Awareness Information Requirements for Commercial Airline Pilots", Cambridge, MA: Massachusetts Institute of Technology International Center for Air Transpotation.

Endsley, M. R. \& Garland, D. J. (Eds.). 2000, "Situation Awareness Analysis and Measurement", Mahwah, NJ: Erlbaum.

Faulkender, M. \& Wang, R. 2006, "Corporate Financial Policy and the Value of Cash", The Journal of Finance, vol. 61, no. 4, pp. 1957-1990. 
Ferris, S.P., Jayaraman, N. \& Sabherwal, S. 2013, "CEO Overconfidence and International Merger and Acquisition Activity", The Journal of Financial and Quantitative Analysis, vol. 48, no. 1, pp. 137-164.

Fresard, L. 2010, "Financial Strength and Product Market Behavior: The Real Effects of Corporate Cash Holdings", The Journal of Finance, vol. 65, no. 3, pp. 1097-1122.

Gao, H., Harford, J. \& Li, K. 2013, "Determinants of Corporate Cash Policy: Insights from Private Firms", Journal of Financial Economics, vol. 109, no. 3, pp. 623-639.

Graham, J.R., Harvey, C.R. \& Puri, M. 2013, "Managerial attitudes and corporate actions", Journal of Financial Economics, vol. 109, no. 1, pp. 103-121.

Graham, J.R., Harvey, C.R. \& Puri, M. 2015, "Capital Allocation and Delegation of Decisionmaking Authority within Firms", Journal of Financial Economics, vol. 115, no. 3, pp. 449470

Hanlon, M., Maydew, E.L. \& Saavedra, D. 2017, "The Taxman Cometh: Does Tax Uncertainty Affect Corporate Cash Holdings?", Review of Accounting Studies, vol. 22, no. 3, pp. 11981228.

Han, S. \& Qiu, J. 2007, "Corporate Precautionary Cash Holdings", Journal of Corporate Finance, vol. 13 , no. 1 , pp. 43-57.

Huang-Meier, W., Lambertides, N. \& Steeley, J.M. 2016, "Motives for Corporate Cash Holdings: The CEO Optimism Effect", Review of Quantitative Finance and Accounting, vol. 47, no. 3, pp. 699-732.

Horne, T. A. 1997, "Measure of Skill: Staying Ahead of the Airplane Setting Goals for each Flight, a step at a time", AOPA Pilot, vol.40, no.6, pp. 45-47.

Keynes, J.M., LJ Hume collection \& La Nauze collection 1936, The general theory of employment interest and money, Macmillan, London.

Liu, Y. \& Mauer, D.C. 2011, "Corporate Cash Holdings and CEO Compensation Incentives", Journal of Financial Economics, vol. 102, no. 1, pp. 183-198.

Malmendier, U. \& Tate, G. 2005, "CEO Overconfidence and Corporate Investment", The Journal of Finance, vol. 60, no. 6, pp. 2661-2700.

Malmendier, U., Tate, G. \& Yan, J. 2011, "Overconfidence and Early-Life Experiences: The Effect of Managerial Traits on Corporate Financial Policies", The Journal of Finance, vol. 66, no. 5, pp. 1687-1733.

Opler, T., Pinkowitz, L., Stulz, R. \& Williamson, R. 1999, "The Determinants and Implications of Corporate Cash Holdings", Journal of Financial Economics, vol. 52, no. 1, pp. 3-46.

Qiu, J. \& Wan, C. 2015, "Technology Spillovers and Corporate Cash Holdings", Journal of Financial Economics, vol. 115, no. 3, pp. 558-573.

Riley, J.M., Endsley, M.R., Bolstad, C.A. \& Cuevas, H.M. 2006, "Collaborative planning and situation awareness in Army command and control", Ergonomics, vol. 49, no. 12-13, pp. 1139-1153.

Sarter, N.B. \& Woods, D.D. 1991, "Situation Awareness: A Critical But Ill-Defined Phenomenon", The International Journal of Aviation Psychology, vol. 1, no. 1, pp. 45-57.

Sunder, S.V., Sunder, J. \& Zhang, J. 2017, "Pilot CEOs and Corporate Innovation", Journal of Financial Economics, vol. 123, no. 1, pp. 209-224. 
Tong, Z. 2010, "CEO Risk Incentives and Corporate Cash Holdings", Journal of Business Finance and Accounting, vol. 37, no. 9-10, pp. 1248-1280.

Tversky, A. \& Kahneman, D. 1973, "Availability: A Heuristic for Judging Frequency and Probability", Cognitive Psychology, vol. 5, no. 2, pp. 207-232.

Tversky, A. \& Kahneman, D. 1974, "Judgment under Uncertainty: Heuristics and Biases", Science, vol. 185, no.4157, pp.1124. 
Fig. 1

Sample Selection Process for Pilot CEOs

\begin{tabular}{|c|c|c|c|c|}
\hline CEOs from 1992 to 2010 & & & & CEOs from 2011 to 2015 \\
\hline \multirow{2}{*}{$\begin{array}{l}\text { Is CEO name in FAA } \\
\text { airmen database? }\end{array}$} & No & Non & No & \multirow{2}{*}{$\begin{array}{l}\text { Is CEO name in FAA } \\
\text { airmen database? }\end{array}$} \\
\hline & \multirow{2}{*}{$\mathrm{n}=4,346$} & & & \\
\hline $\begin{array}{l}\text { Yes } \\
n=2,179\end{array}$ & & & & $\mid \begin{array}{l}\text { Yes } \\
n=406\end{array}$ \\
\hline \multirow{2}{*}{$\begin{array}{l}\text { Is CEO name in the } \\
\text { pilot CEOs list of Cain } \\
\text { and McKeon? }\end{array}$} & No & \multirow{2}{*}{ Excluded } & No & \multirow{2}{*}{$\begin{array}{l}\text { If the match remains } \\
\text { valid after verifying } \\
\text { CEOs date of birth? }\end{array}$} \\
\hline & $\mathrm{n}=2,000$ & & $\mathrm{n}=340$ & \\
\hline $\begin{array}{l}\text { Yes } \\
\mathrm{n}=179\end{array}$ & & & & $\begin{array}{l}\text { Yes } \\
n=66\end{array}$ \\
\hline Pilot CEOs & & & & Pilot CEOs \\
\hline
\end{tabular}




\section{Table 1}

Descriptive Statistics of Pilot CEOs

Panel A: Distribution of CEO Pilots by Certificate Level

Pilot certificate level

No.

Student pilot

Private pilot

Commercial pilot

Airline transport pilot

No certificate display

Total

Panel B: Distribution of CEO Pilots by Certificate Rating

Rating

Single engine airplane

Instrument rating

Multiengine airplane

Helicopter

Glider

Sea landing

Hot air balloon

Panel C: CEO Characteristics Variable Correlations

\begin{tabular}{lccccccc} 
& PILOT & VEGA & DELTA & CASH_CO & CONF & AGE & TENURE \\
\cline { 2 - 8 } PILOT & 1 & & & & & & \\
VEGA & $0.061^{*}$ & 1 & & & & & \\
DELTA & $0.031^{*}$ & $0.595^{*}$ & 1 & & & & \\
CASH_COM & $0.031^{*}$ & $0.388^{*}$ & $0.379^{*}$ & 1 & & & \\
OVERCONFIDENCE & 0.000 & $-0.085^{*}$ & $-0.243^{*}$ & $-0.053^{*}$ & 1 & & \\
AGE & $-0.021^{*}$ & $0.051^{*}$ & $0.187^{*}$ & $0.153^{*}$ & $0.047^{*}$ & 1 & \\
TENURE & $0.028^{*}$ & $0.081^{*}$ & $0.149^{*}$ & $0.068^{*}$ & $-0.016^{*}$ & $0.039^{*}$ & 1 \\
\hline
\end{tabular}

This table is descriptive statistics for the pilot CEOs. The sample contain 245 pilot CEOs in this study. Panel A reports the certificate levels attained by the pilot CEOs. Panel B reports the number of pilot CEOs by aircraft certificate ratings. These ratings are not mutually exclusive. Panel $\mathrm{C}$ reports the correlation coefficients for a variety of CEO characteristics, with * denoting correlations significant at $5 \%$ level or greater. 


\section{Table 2}

Descriptive Statistics of Firm-Year Observations

\begin{tabular}{lcccccc}
\hline Panel A & $(1)$ & $(2)$ & $(3)$ & $(4)$ & $(5)$ & $(6)$ \\
\hline Variable & $\mathrm{N}$ & Mean & Std. Dev. & Q1 & Median & Q3 \\
\hline Dependent Variables & & & & & & \\
CASH & 17,860 & 0.156 & 0.164 & 0.028 & 0.089 & 0.213 \\
Firm Characteristics & & & & & & \\
NWC & 17,860 & 0.074 & 0.149 & -0.013 & 0.064 & 0.163 \\
LEVERAGE & 17,860 & 0.226 & 0.200 & 0.066 & 0.211 & 0.337 \\
CF_VOL & 17,860 & 0.039 & 0.064 & 0.014 & 0.023 & 0.040 \\
MB & 17,860 & 2.056 & 1.485 & 1.225 & 1.589 & 2.247 \\
SIZE & 17,860 & 7.362 & 1.591 & 6.236 & 7.233 & 8.373 \\
DIVIDENT & 17,860 & 0.506 & 0.500 & 0.000 & 1.000 & 1.000 \\
CAPEX & 17,860 & 0.055 & 0.054 & 0.021 & 0.038 & 0.069 \\
AQU & 17,860 & 0.030 & 0.063 & 0.000 & 0.001 & 0.027 \\
CFL & 17,860 & 0.079 & 0.091 & 0.050 & 0.083 & 0.118 \\
R\&D & 17,860 & 0.034 & 0.066 & 0.000 & 0.003 & 0.040 \\
TANGIBILITY & 17,860 & 0.277 & 0.222 & 0.105 & 0.209 & 0.391 \\
SALES_G & 17,860 & 1.117 & 0.628 & 0.991 & 1.073 & 1.173 \\
ROE & 17,860 & 0.155 & 0.128 & 0.096 & 0.148 & 0.211 \\
CEOCCharacteristics & & & & & & \\
VEGA & 17,860 & 3.411 & 1.822 & 2.358 & 3.625 & 4.692 \\
DELTA & 17,860 & 5.128 & 1.721 & 4.067 & 5.117 & 6.209 \\
CASH_COM & 17,860 & 1062.259 & 1476.473 & 501.000 & 772.231 & 1150.000 \\
OVERCON & 17,860 & 0.770 & 0.421 & 1.000 & 1.000 & 1.000 \\
AGE & 17,860 & 3.987 & 0.147 & 3.892 & 3.989 & 4.078 \\
TENURE & 17,860 & 6.759 & 4.957 & 3.000 & 6.000 & 9.000 \\
\hline
\end{tabular}




\begin{tabular}{|c|c|c|c|c|c|c|}
\hline \multirow[t]{2}{*}{ Panel B } & \multicolumn{2}{|c|}{ Non-pilot CEOs } & \multicolumn{2}{|c|}{ Pilot CEOs } & \multicolumn{2}{|c|}{ t-test } \\
\hline & $\mathrm{N}$ & Mean & $\mathrm{N}$ & Mean & Difference & $p$-value \\
\hline \multicolumn{7}{|l|}{ Dependent Variable } \\
\hline $\mathrm{CASH}$ & 16,153 & 0.149 & 1,707 & 0.162 & $-0.013^{*}$ & 0.088 \\
\hline \multicolumn{7}{|l|}{ Firm Characteristics } \\
\hline$N W C$ & 16,153 & 0.076 & 1,707 & 0.047 & $0.028^{* * *}$ & 0.000 \\
\hline LEVERAGE & 16,153 & 0.225 & 1,707 & 0.236 & $-0.011^{* *}$ & 0.021 \\
\hline$C F L \_V O L$ & 16,153 & 0.039 & 1,707 & 0.038 & 0.002 & 0.352 \\
\hline$M B$ & 16,153 & 2.117 & 1,707 & 2.049 & $0.068^{*}$ & 0.096 \\
\hline SIZE & 16,153 & 7.254 & 1,707 & 7.676 & $-7.286^{* * *}$ & 0.000 \\
\hline CAPEX & 16,153 & 0.056 & 1,707 & 0.057 & -0.001 & 0.444 \\
\hline$A Q U$ & 16,153 & 0.029 & 1,707 & 0.026 & 0.002 & 0.201 \\
\hline$\widehat{C F L}$ & 16,153 & 0.073 & 1,707 & 0.078 & $-0.005^{* *}$ & 0.032 \\
\hline$R \& D$ & 16,153 & 0.035 & 1,707 & 0.036 & -0.001 & 0.768 \\
\hline TANGIBILITY & 16,153 & 0.272 & 1,707 & 0.294 & $-0.022^{* * *}$ & 0.000 \\
\hline SALES_G & 16,153 & 1.145 & 1,707 & 1.111 & 0.035 & 0.481 \\
\hline$R O E$ & 16,153 & 0.157 & 1,707 & 0.154 & 0.003 & 0.350 \\
\hline DIVIDENT & 16,153 & 0.489 & 1,707 & 0.563 & -0.074 & 0.000 \\
\hline \multicolumn{7}{|l|}{ CEO Characteristics } \\
\hline$A G E$ & 16,153 & 4.000 & 1,707 & 3.980 & $0.012^{* * *}$ & 0.000 \\
\hline TENURE & 16,153 & 6.383 & 1,707 & 6.783 & $-0.400^{* * *}$ & 0.000 \\
\hline CASH_COM & 16,153 & 972.564 & 1,707 & 1076.925 & $-104.361^{* * *}$ & 0.000 \\
\hline DELTA & 16,153 & 4.780 & 1,707 & 4.933 & $-0.154^{* * *}$ & 0.000 \\
\hline$V E G A$ & 16,153 & 3.140 & 1,707 & 3.503 & $-0.362^{* * *}$ & 0.000 \\
\hline OVERCONFIDENCE & 16,153 & 0.784 & 1,707 & 0.792 & $-0.008^{* * *}$ & 0.380 \\
\hline \multicolumn{7}{|c|}{$\begin{array}{l}\text { This table reports summary statistics for both firm characteristics and CEO statistics. The sample is based on all pilot CEOs and } \\
\text { non-pilot CEOs from the ExecuComp 1992-2015 identified at Fig. } 1 \text { and the firms were matched to these CEOs. Differences } \\
\text { between the means for pilot CEOs firms and non-pilot CEOs firms are tested using t-tests (Wilcoxon-Mann-Whitney tests). The } \\
\text { symbols ***,**, and * denote significant differences between the firms with and without pilot CEOs at the } 1 \%, 5 \% \text { and } 10 \% \\
\text { level, respectively. }\end{array}$} \\
\hline
\end{tabular}




\begin{tabular}{|c|c|c|}
\hline \multicolumn{3}{|c|}{$\begin{array}{c}\text { Table } 3 \\
\text { Pilot CEOs and Corporate Cash Holdings }\end{array}$} \\
\hline Variables & Coefficients & p-value \\
\hline PILOT & $0.014^{* *}$ & $(0.049)$ \\
\hline$V E G A$ & $-0.003^{* * *}$ & $(0.006)$ \\
\hline DELTA & $0.007^{* * *}$ & $(0.000)$ \\
\hline CASH_COM & -0.000 & $(0.423)$ \\
\hline OVERCONFIDENCE & -0.001 & $(0.809)$ \\
\hline$A G E$ & -0.018 & $(0.171)$ \\
\hline TENURE & $0.001^{* * *}$ & $(0.000)$ \\
\hline$N W C$ & $-0.204^{* * *}$ & $(0.000)$ \\
\hline LEVERAGE & $-0.126^{* * *}$ & $(0.000)$ \\
\hline$C F L \_V O L$ & 0.051 & $(0.130)$ \\
\hline$M B$ & $0.013^{* * *}$ & $(0.000)$ \\
\hline SIZE & $-0.021^{* * *}$ & $(0.000)$ \\
\hline DVIDEND & -0.006 & $(0.166)$ \\
\hline CAPEX & $-0.229^{* * *}$ & $(0.000)$ \\
\hline$A Q U$ & $-0.225^{* * *}$ & $(0.000)$ \\
\hline$\widetilde{C F L}$ & -0.020 & $(0.574)$ \\
\hline$R \& D$ & $0.226^{* * *}$ & $(0.000)$ \\
\hline TANGIBILITY & $-0.180^{* * *}$ & $(0.000)$ \\
\hline$S A L E S \_G$ & 0.002 & $(0.408)$ \\
\hline$R O E$ & -0.023 & $(0.497)$ \\
\hline Constant & $0.340^{* * *}$ & $(0.000)$ \\
\hline Industry Fixed Effect & Yes & \\
\hline Year Fixed Effect & Yes & \\
\hline No. of observations & 17,860 & \\
\hline Adjusted R-squared & 0.493 & \\
\hline
\end{tabular}


Table 4

Pilot CEOs and the Value of Cash Holdings

\begin{tabular}{|c|c|c|}
\hline Variables & Coefficients & $p$-value \\
\hline PILOT & $1.310^{* * * *}$ & $(0.000)$ \\
\hline$P I L O T * \triangle C A S H$ & $1.753^{* *}$ & $(0.037)$ \\
\hline$\triangle C A S H$ & 0.837 & $(0.204)$ \\
\hline$\triangle E A R N$ & 0.078 & $(0.616)$ \\
\hline$\Delta N A$ & $0.524^{* * *}$ & $(0.000)$ \\
\hline$\Delta R \& D$ & 0.742 & $(0.554)$ \\
\hline$\Delta I$ & $-9.072^{* *}$ & $(0.010)$ \\
\hline$\Delta D$ & $9.823^{* *}$ & $(0.033)$ \\
\hline $\mathrm{CASH}$ & $-0.752^{* * *}$ & $(0.000)$ \\
\hline$L E V$ & $-2.291^{* * *}$ & $(0.000)$ \\
\hline$C A S H^{*} \triangle C A S H$ & -0.050 & $(0.212)$ \\
\hline$L E V E R A G E^{*} \triangle C A S H$ & -0.038 & $(0.959)$ \\
\hline NEWFIN & $-0.960^{* * *}$ & $(0.002)$ \\
\hline DELTA & $0.086^{* * *}$ & $(0.000)$ \\
\hline$V E G A$ & $0.235^{* * *}$ & $(0.000)$ \\
\hline$D E L T A * \triangle C A S H$ & $0.313^{*}$ & $(0.074)$ \\
\hline$V E G A * \triangle C A S H$ & $0.364^{*}$ & $(0.082)$ \\
\hline Constant & $-1.439^{* * *}$ & $(0.000)$ \\
\hline Industry Fixed Effect & Yes & \\
\hline Year Fixed Effect & Yes & \\
\hline No. of observations & 19,015 & \\
\hline Adjusted R-squared & 0.389 & \\
\hline
\end{tabular}


Table 5

Certificate Levels and Corporate Cash Holdings

\begin{tabular}{lcc}
\hline Variables & Coefficients & p-value \\
\hline HIGHLEVEL & $\mathbf{0 . 0 4 0 ^ { * * * * }}$ & $\mathbf{( 0 . 0 0 9 )}$ \\
LOWLEVEL & $\mathbf{0 . 0 0 5}$ & $\mathbf{( 0 . 4 8 1 )}$ \\
VEGA & $-0.002^{* *}$ & $(0.042)$ \\
DELTA & $0.006^{* * *}$ & $(0.000)$ \\
CASH_COM & -0.000 & $(0.637)$ \\
OVERCONFIDENCE & 0.001 & $(0.607)$ \\
AGE & -0.006 & $(0.661)$ \\
TENURE & $0.001^{* *}$ & $(0.018)$ \\
NWC & $-0.265^{* * *}$ & $(0.000)$ \\
LEVERAGE & $-0.132^{* * *}$ & $(0.000)$ \\
CFL_VOL & $0.108^{* * *}$ & $(0.006)$ \\
MB & $0.012^{* * *}$ & $(0.000)$ \\
SIZE & $-0.026^{* * *}$ & $(0.000)$ \\
DVIDEND & -0.007 & $(0.118)$ \\
CAPEX & $-0.240^{* * *}$ & $(0.000)$ \\
AQU & $-0.250^{* * *}$ & $(0.000)$ \\
CFL & $-0.067^{*}$ & $(0.097)$ \\
R\&D & $0.235^{* * *}$ & $(0.000)$ \\
TANGIBILITY & $-0.202^{* * *}$ & $(0.000)$ \\
SALES_G & 0.001 & $(0.698)$ \\
ROE & -0.008 & $(0.806)$ \\
Constant & $0.351^{* * *}$ & $(0.000)$ \\
Industry Fixed Effect & Yes & \\
Year Fixed Effect & Yes & \\
No. of observations & 17,860 & \\
Adjusted $R$-squared & 0.569 & \\
\hline This table reports the results from OLS regressions of corporate cash holdings on pilot CEOs. Variables definitions are provided \\
in the Appendix 1. Robust standard errors are clustered at the firm level and year. p-values are in parentheses. ***, **, and * \\
denote significant at the 1\%, 5\% and 10\% level, respectively. & \\
\hline & &
\end{tabular}




\section{Table 6}

Certificate Levels and the Value of Cash Holdings

\begin{tabular}{|c|c|c|}
\hline Variables & Coefficients & $p$-value \\
\hline HIGHLEVEL & $1.469^{* * *}$ & $(0.000)$ \\
\hline LOWLEVEL & $1.239^{* *}$ & $(0.000)$ \\
\hline HIGHLEVEL $* \triangle C A S H$ & $5.796^{* * * *}$ & $(0.007)$ \\
\hline LOWLEVEL $* \triangle C A S H$ & 1.064 & $(0.227)$ \\
\hline$\triangle C A S H$ & 0.735 & $(0.267)$ \\
\hline$\triangle E A R N$ & 0.067 & $(0.664)$ \\
\hline$\triangle N A$ & $0.513^{* * *}$ & $(0.000)$ \\
\hline$\Delta R \& D$ & 0.766 & $(0.544)$ \\
\hline$\Delta I$ & $-9.103^{* *}$ & $(0.010)$ \\
\hline$\Delta D$ & $9.769^{* *}$ & $(0.034)$ \\
\hline CASH & $-0.748^{* * * *}$ & $(0.000)$ \\
\hline$L E V$ & $-2.304^{* * *}$ & $(0.000)$ \\
\hline$C A S H^{*} \triangle C A S H$ & -0.053 & $(0.188)$ \\
\hline LEVERAGE* $\triangle C A S H$ & 0.023 & $(0.974)$ \\
\hline NEWFIN & $-0.957^{* * *}$ & $(0.002)$ \\
\hline DELTA & $0.086^{* * *}$ & $(0.000)$ \\
\hline$V E G A$ & $0.234^{* * *}$ & $(0.000)$ \\
\hline$D E L T A * \triangle C A S H$ & $-0.310^{*}$ & $(0.079)$ \\
\hline$V E G A^{*} \triangle C A S H$ & $0.369^{*}$ & $(0.079)$ \\
\hline Constant & $-1.436^{* * *}$ & $(0.000)$ \\
\hline Industry Fixed Effect & Yes & \\
\hline Year Fixed Effect & Yes & \\
\hline No. of observations & 19,015 & \\
\hline Adjusted R-squared & 0.402 & \\
\hline
\end{tabular}


Table 7

Subsample Analysis: Growth Opportunities

\begin{tabular}{|c|c|c|c|c|}
\hline \multirow[b]{2}{*}{ Variables } & \multicolumn{2}{|c|}{ Low Growth Opportunities } & \multicolumn{2}{|c|}{ High Growth Opportunities } \\
\hline & Coefficient & $p$-value & Coefficient & $p$-value \\
\hline PILOT & $\mathrm{0.015}^{*}$ & $(0.064)$ & $0.026{ }^{* *}$ & $(0.022)$ \\
\hline$V E G A$ & -0.001 & $(0.398)$ & $-0.004^{* *}$ & $(0.011)$ \\
\hline DELTA & $0.006^{* * *}$ & $(0.000)$ & $0.008^{* * *}$ & $(0.000)$ \\
\hline CASH_COM & $0.000^{* * *}$ & $(0.003)$ & $-0.000^{* * *}$ & $(0.001)$ \\
\hline OVERCONFIDENCE & -0.001 & $(0.812)$ & $0.006^{*}$ & $(0.096)$ \\
\hline$A G E$ & -0.012 & $(0.371)$ & 0.007 & $(0.702)$ \\
\hline TENURE & 0.000 & $(0.983)$ & $0.001^{* *}$ & $(0.025)$ \\
\hline$N W C$ & $-0.286^{* * *}$ & $(0.000)$ & $-0.260^{* * *}$ & $(0.000)$ \\
\hline LEVERAGE & $-0.172^{* * *}$ & $(0.000)$ & $-0.098^{* * *}$ & $(0.000)$ \\
\hline$C F L \_V O L$ & $0.123^{* * *}$ & $(0.009)$ & 0.046 & $(0.277)$ \\
\hline$M B$ & 0.000 & $(0.424)$ & -0.000 & $(0.180)$ \\
\hline SIZE & $-0.027^{* * * *}$ & $(0.000)$ & $-0.026^{* * *}$ & $(0.000)$ \\
\hline DVIDEND & $-0.011^{* *}$ & $(0.030)$ & -0.010 & $(0.113)$ \\
\hline CAPEX & $-0.257^{* * *}$ & $(0.000)$ & $-0.206^{* * *}$ & $(0.000)$ \\
\hline$A Q U$ & $-0.166^{* * *}$ & $(0.000)$ & $-0.405^{* * *}$ & $(0.000)$ \\
\hline$C F L$ & $-0.072^{*}$ & $(0.054)$ & $-0.097^{* * * *}$ & $(0.007)$ \\
\hline$R \& D$ & $0.241^{* * *}$ & $(0.009)$ & $0.240^{* * *}$ & $(0.000)$ \\
\hline TANGIBILITY & $-0.170^{* * *}$ & $(0.000)$ & $-0.291^{* * *}$ & $(0.000)$ \\
\hline SALES_G & 0.000 & $(0.981)$ & $0.008^{* *}$ & $(0.019)$ \\
\hline$R O E$ & -0.044 & $(0.193)$ & 0.026 & $(0.374)$ \\
\hline Constant & $0.414^{* * *}$ & $(0.000)$ & $0.376^{* * *}$ & $(0.000)$ \\
\hline Industry Fixed Effect & Yes & & Yes & \\
\hline Year Fixed Effect & Yes & & Yes & \\
\hline No. of observations & 9,673 & & 8,187 & \\
\hline Adjusted R-squared & 0.556 & & 0.607 & \\
\hline
\end{tabular}

This table reports the results from OLS regressions of corporate cash holdings on pilot CEOs. Variables definitions are provided in the Appendix 1. Robust standard errors are clustered at the firm level and year. p-values are in parentheses. ***, **, and * denote significant at the $1 \%, 5 \%$ and $10 \%$ level, respectively. 


\section{Table 8}

Subsample Analysis: Financial Constraints

\begin{tabular}{|c|c|c|c|c|}
\hline \multirow[b]{2}{*}{ Variables } & \multicolumn{2}{|c|}{ Financially unconstrained } & \multicolumn{2}{|c|}{ Financially constrained } \\
\hline & Coefficient & $p$-value & Coefficient & p-value \\
\hline PILOT & 0.015 & $(\mathbf{0 . 1 3 9})$ & $\mathbf{0 . 0 2 0}{ }^{* *}$ & $(\mathbf{0 . 0 3 8 )}$ \\
\hline$V E G A$ & $-0.004^{* * *}$ & $(0.006)$ & -0.002 & $(0.185)$ \\
\hline DELTA & $0.008^{* * *}$ & $(0.000)$ & $0.009^{* * *}$ & $(0.000)$ \\
\hline CASH_COM & $-0.000^{* * * *}$ & $(0.007)$ & $0.000^{* * * *}$ & $(0.001)$ \\
\hline OVERCONFIDENCE & 0.005 & $(0.123)$ & 0.002 & $(0.691)$ \\
\hline$A G E$ & 0.005 & $(0.769)$ & -0.027 & $(0.100)$ \\
\hline TENURE & $0.001^{*}$ & $(0.066)$ & 0.000 & $(0.652)$ \\
\hline$N W C$ & $-0.301^{* * *}$ & $(0.000)$ & $-0.282^{* * *}$ & $(0.000)$ \\
\hline LEVERAGE & $-0.111^{* * *}$ & $(0.000)$ & $-0.151^{* * *}$ & $(0.000)$ \\
\hline$C F L \_V O L$ & $0.124^{* *}$ & $(0.016)$ & $0.095^{* *}$ & $(0.022)$ \\
\hline$M B$ & 0.000 & $(0.657)$ & -0.000 & $(0.742)$ \\
\hline SIZE & $-0.029^{* * * *}$ & $(0.000)$ & $-0.026^{* * *}$ & $(0.000)$ \\
\hline DVIDEND & $-0.011^{*}$ & $(0.069)$ & $-0.018^{* * *}$ & $(0.001)$ \\
\hline CAPEX & $-0.233^{* * *}$ & $(0.000)$ & $-0.227^{* * *}$ & $(0.000)$ \\
\hline$A Q U$ & $-0.329^{* * *}$ & $(0.000)$ & $-0.246^{* * *}$ & $(0.000)$ \\
\hline$C F L$ & $-0.151^{* * * *}$ & $(0.000)$ & $-0.074^{* *}$ & $(0.047)$ \\
\hline$R \& D$ & $0.245^{* * *}$ & $(0.000)$ & $0.295^{* * *}$ & $(0.000)$ \\
\hline TANGIBILITY & $-0.241^{* * *}$ & $(0.000)$ & $-0.214^{* * *}$ & $(0.000)$ \\
\hline$S A L E S \_G$ & -0.001 & $(0.309)$ & $0.009^{* * *}$ & $(0.002)$ \\
\hline$R O E$ & $0.093^{* * *}$ & $(0.008)$ & 0.027 & $(0.464)$ \\
\hline Constant & $0.402^{* * *}$ & $(0.000)$ & $0.451^{* * *}$ & $(0.000)$ \\
\hline Industry Fixed Effect & Yes & & Yes & \\
\hline Year Fixed Effect & Yes & & Yes & \\
\hline No. of observations & 9,004 & & 8,856 & \\
\hline Adjusted R-squared & 0.584 & & 0.573 & \\
\hline
\end{tabular}

This table reports the results from OLS regressions of corporate cash holdings on pilot CEOs. Variables definitions are provided in the Appendix 1. Robust standard errors are clustered at the firm level and year. p-values are in parentheses. ***, **, and * denote significant at the $1 \%, 5 \%$ and $10 \%$ level, respectively. 
Table 9

Pilot CEO Turnover Analysis

\begin{tabular}{lcc}
\hline Variables & Coefficients & $p$-value \\
\hline PILOTTURNOVER & $\mathbf{0 . 0 5 2}$ & $(\mathbf{0 . 0 1 3})$ \\
$\Delta$ VEGA & 0.001 & $(0.918)$ \\
$\Delta$ DELTA & -0.006 & $(0.362)$ \\
$\Delta$ CASH_COM & 0.000 & $(0.473)$ \\
$\Delta$ OVERCONFIDENCE & -0.002 & $(0.948)$ \\
$\Delta$ AGE & -0.004 & $(0.937)$ \\
ITENURE & 0.003 & $(0.122)$ \\
Yeartry Fixed Effect & Yes & \\
No. of observations & Yes & \\
Adjusted R-squared & 319 & \\
\hline
\end{tabular}

This table reports the results from OLS regression of change in corporate cash holdings on change in pilot CEOs for after controlling for other CEO characteristics changes. The changes estimated from year $t-1$ to year $t+1$. Change in cash holdings is measured as the difference between the cash-to-asset ratio $(C A S H)$ after the new CEO takes office and the cash-to-asset ratio measured when the previous CEO was in power. The pilot CEO turnover (PILOTTURNOVER) year is year $\mathrm{t}-1 . * * *, * *$, and * denote significant at the $1 \%, 5 \%$ and $10 \%$ level, respectively. 


\section{Table 10}

Pilot CEOs and Corporate Cash Holdings (Controlling for Military Experience)

\begin{tabular}{|c|c|c|}
\hline Variables & Coefficients & $p$-value \\
\hline PILOT & $\mathbf{0 . 0 2 8}^{*}$ & $(0.051)$ \\
\hline MILITARY & 0.020 & $(0.169)$ \\
\hline$V E G A$ & -0.002 & $(0.101)$ \\
\hline DELTA & $0.004^{* *}$ & $(0.043)$ \\
\hline CASH_COM & 0.000 & $(0.367)$ \\
\hline OVERCONFIDENCE & -0.001 & $(0.922)$ \\
\hline$A G E$ & 0.013 & $(0.518)$ \\
\hline TENURE & -0.000 & $(0.889)$ \\
\hline$N W C$ & $-0.188^{* * * *}$ & $(0.000)$ \\
\hline LEVERAGE & $-0.092^{* * *}$ & $(0.000)$ \\
\hline$C F L \_V O L$ & $0.313^{* * *}$ & $(0.000)$ \\
\hline$M B$ & 0.000 & $(0.510)$ \\
\hline SIZE & $-0.016^{* * *}$ & $(0.000)$ \\
\hline DVIDEND & 0.001 & $(0.881)$ \\
\hline CAPEX & $-0.231^{* * *}$ & $(0.006)$ \\
\hline$A Q U$ & $-0.138^{* * *}$ & $(0.000)$ \\
\hline$C F L$ & -0.055 & $(0.334)$ \\
\hline$R \& D$ & $0.316^{* * *}$ & $(0.002)$ \\
\hline TANGIBILITY & $-0.104^{* * *}$ & $(0.000)$ \\
\hline SALES_G & -0.001 & $(0.940)$ \\
\hline$R O E$ & 0.060 & $(0.218)$ \\
\hline Constant & $0.277^{* * *}$ & $(0.004)$ \\
\hline Industry Fixed Effect & Yes & \\
\hline Year Fixed Effect & Yes & \\
\hline No. of observations & 4,174 & \\
\hline Adjusted R-squared & 0.306 & \\
\hline
\end{tabular}




\section{Table 11}

Pilot CEOs and Corporate Cash Holdings (Log of Cash-to-Assets Ratio)

\begin{tabular}{|c|c|c|}
\hline Variables & Coefficients & p-value \\
\hline PILOT & $\mathbf{0 . 1 3 3}^{* * *}$ & $(0.008)$ \\
\hline$V E G A$ & -0.014 & $(0.156)$ \\
\hline DELTA & $0.030^{* *}$ & $(0.013)$ \\
\hline CASH_COM & -0.000 & $(0.191)$ \\
\hline OVERCONFIDENCE & $0.039^{*}$ & $(0.095)$ \\
\hline$A G E$ & 0.028 & $(0.795)$ \\
\hline TENURE & $0.004^{* *}$ & $(0.031)$ \\
\hline$N W C$ & $-1.591^{* * *}$ & $(0.000)$ \\
\hline LEVERAGE & $-1.179^{* * *}$ & $(0.000)$ \\
\hline$C F L \_V O L$ & $0.798^{* * *}$ & $(0.002)$ \\
\hline$M B$ & $0.098^{* * *}$ & $(0.000)$ \\
\hline SIZE & $-0.105^{* * *}$ & $(0.000)$ \\
\hline DVIDEND & $-0.082^{* *}$ & $(0.041)$ \\
\hline CAPEX & $-1.355^{* * *}$ & $(0.000)$ \\
\hline$A Q U$ & $-2.034^{* * *}$ & $(0.000)$ \\
\hline$\widetilde{C F L}$ & $-0.487^{* * *}$ & $(0.007)$ \\
\hline$R \& D$ & $0.672^{* *}$ & $(0.017)$ \\
\hline TANGIBILITY & $-1.605^{* * *}$ & $(0.000)$ \\
\hline$S A L E S \_G$ & -0.012 & $(0.386)$ \\
\hline$R O E$ & $0.359^{* *}$ & $(0.024)$ \\
\hline Constant & $-1.712^{* * *}$ & $(0.001)$ \\
\hline Industry Fixed Effect & Yes & \\
\hline Year Fixed Effect & Yes & \\
\hline No. of observations & 17,860 & \\
\hline Adjusted. $R$-square squared & 0.519 & \\
\hline
\end{tabular}




\section{Appendix 1. Variable Definitions}

\begin{tabular}{|c|c|c|}
\hline CEO characteristics & Definition & Data source \\
\hline PILOT & $\begin{array}{l}\text { An indicator variable equal to } 1 \text { if CEO has had certificate in FAA } \\
\text { airmen database, and } 0 \text { otherwise. }\end{array}$ & FAA \\
\hline DELTA & $\begin{array}{l}\text { Dollar change in CEO stock and option portfolio value for a } 1 \% \\
\text { change in stock price. }\end{array}$ & \\
\hline$V E G A$ & $\begin{array}{l}\text { Dollar change in CEO option holdings value for a } 1 \% \text { change in } \\
\text { stock return volatility. }\end{array}$ & \\
\hline CASH_COM & $($ SALARY+BONUS) & ExecuComp \\
\hline OVERCONFIDENCE & $\begin{array}{l}\text { An indicator variable equal to } 1 \text { if the CEO's options exceed } 100 \% \\
\text { moneyness in the current period or any prior period. }\end{array}$ & ExecuComp \\
\hline TENURE & Number of years of service as CEO at given firm. & ExecuComp \\
\hline$A G E$ & The natural logarithm of CEO's age & ExecuComp \\
\hline \multicolumn{3}{|l|}{ Firm characteristics } \\
\hline$N W C$ & $\begin{array}{l}\text { Net working capital is defined as working capital minus cash } \\
\text { holdings scaled by total assets (WCAP-CHE)/AT. }\end{array}$ & Compustat \\
\hline LEVERAGE & $\begin{array}{l}\text { The sum of long-term debt and debt in current liabilities divided by } \\
\text { total assets (DLTT + DLC)/AT. }\end{array}$ & \\
\hline$M B$ & $\begin{array}{l}\text { Market-to-book ratio is measured as the market value of equity plus } \\
\text { the book value of total assets reduced by the book value of equity, } \\
\text { then divided by the total assets (CSHO*PRCC_F+AT-CEQ)/AT. }\end{array}$ & Compustat \\
\hline SIZE & Firm size is measures as natural logarithm of total assets (AT). & Compustat \\
\hline CAPEX & $\begin{array}{l}\text { Capital expenditure is measured as a ratio of total capital } \\
\text { expenditures divided by the total assets CAPX/AT. }\end{array}$ & Compustat \\
\hline DIVIDEND & $\begin{array}{l}\text { An indicator variable equal one in years in which a firm pays a } \\
\text { common dividend (DVC) and zero otherwise. }\end{array}$ & Compustat \\
\hline$A Q U$ & $\begin{array}{l}\text { Acquisition is measured as the current year total acquisitions } \\
\text { expenses scaled by total assets AQC/AT. }\end{array}$ & \\
\hline$C F L$ & $\begin{array}{l}\text { Free cash flow is measured as earnings after interest, tax and } \\
\text { dividend, divided by total assets (OIBDP-XINT-TXT-DVC)/AT. }\end{array}$ & \\
\hline$R \& D$ & $\begin{array}{l}R \& D \text { is measured as the total research and development expenses } \\
\text { scaled by total assets XRD/AT. }\end{array}$ & Compustat \\
\hline TANGIBILITY & $\begin{array}{l}\text { Tangibility is measured as the net value of property, plants, and } \\
\text { equipment divided by total assets PPENT/AT. }\end{array}$ & Compustat \\
\hline SALES_G & $\begin{array}{l}\text { Sales growth is measured as the current year total revenue (REVT) } \\
\text { divided by the one year lagged total revenue. }\end{array}$ & Compustat \\
\hline$R O E$ & $\begin{array}{l}\text { Return on equity is measured as a ratio of earnings before interest } \\
\text { (EBITDA) divided by one year lagged total assets (AT). }\end{array}$ & Compustat \\
\hline$E A R N$ & Earnings before extraordinary items (OIDBP). & Compustat \\
\hline$N A$ & $\begin{array}{l}\text { Net assets, calculated by total assets minus cash and marketable } \\
\text { securities (AT-CHE). }\end{array}$ & Compustat \\
\hline$I$ & Interest expenses (XINT) & Compustat \\
\hline$D$ & Common dividends (DVC). & Compustat \\
\hline NEWFIN & $\begin{array}{l}\text { Net new finance at year } t \text {, is measured as the sum of net new equity } \\
\text { issues (SSTK-PRSTKC) and net new debt issues (DLTIS-DLTR). }\end{array}$ & Compustat \\
\hline
\end{tabular}

